and for his scrupulous and comprehensive editions of the works of Afanasii Nikitin and Iosif Volotskii and of the Kurbskii-Groznyi correspondence. Leaving an appreciation of these major contributions to a more appropriate occasion, here one can only note Iakov Solomonovich's great productivity, the more astonishing for having been achieved under conditions that were often very adverse, not only as a conse. quence of wartime conditions or anti-Semitic campaigns, but no doubt in part because of his utter fearlessness in the face of official academic derzhimordstwo.

Two particularly vivid episodes come to mind. The first took place in 1962-63, during one of the more disgraceful episodes in the history of Soviet "scholarship": the collective pillorying of Aleksandr Zimin for having suggested that the Igor Tale was a late eighteenth-century pastiche, composed by a Ruthenian monk, Ioil' Bykovskii. As is now clear from partially published correspondence, Lur'e, who did not himself accept Zimin's conclusions, was almost alone in refusing to participate in the closed "discussion" that was led and orchestrated by Dmitrii S. Likhachev. Lur'e's courage is the more remarkable for the fact that Likhachev was his quondam patron, nominal boss, and arguably the most powerful humanist in the Academy.

Lur'e's expulsion from the Pushkinskij dom was the direct result of his willingness to stand as character witness for his assistant Arsenii Roginskii, who had been arrested after it was discovered that he was the editor and publisher of the fine tamizdat doc. umentary albums Pamiat' (5 vols., 1978-82). Certainly these and other acts of civic courage and intellectual autonomy explain a seeming paradox: while universally acknowledged as Russia's leading medievalist, Lur'e was never awarded any of the honorary titles and prizes made so much of in the Soviet Academy and showered upon charlatans and complaisant nonentities.

Widely known for his sharp tongue and warmly admired for his integrity, Iakov Solomonovich was, as the present writer can attest, a ferocious debater, a formidable but always punctiliously just adversary. His death is a particularly grievous loss for the community of Russian medievalists in these generally calamitous times. He is survived by his wife, Irina E. Ganelina, a son, Lev, and two grandchildren, all of St. Petersburg.

EDWARD L. KrHNAN Harvard University May 1996

\title{
Viktor G. Bortnevskii, 1954-1996
}

Viktor Bortnevskii's research specialty was the White Army and administration during the Russian Civil War (1918-21). In both his scholarly and his public life, he worked tirelessly to paint an accurate picture of Russia's lost anti-Bolshevik alternatives and to bring to the current generation a feeling for the Russian cultural and social world that was interrupted by 1917 .

His active career spanned the Soviet, perestroika, and post-Soviet periods of recent Russian history. Even before it was fashionable in Russia to do so, his work represented an attempt to deal fairly and objectively with the White movement in the Russian Civil War. Never one to hide his views, his forthright statements and writings on both Russian history and public policy earned him powerful enemies and a place on the secret list of those to be arrested in Petersburg, had the 1991 coup succeeded.

Equally important was his pioneering interview work with surviving veterans of the White Army in the west. He sought out these veterans wherever they could be 
found in the United States and Europe and interviewed them with sophistication, tact, and respect. Audiences of Russian émigrés wept with joy to find, for the first time, a "Soviet" historian who was making a serious and sensitive attempt to understand the events in which they had participated. At the same time, Bortnevskii was a scholar, not a partisan, and his first loyalty was to scholarly traditions and standards.

Viktor believed in sharing his knowledge with students and with the public. A graduate of Leningrad State University in 1980 and the Russian Academy of Sciences, he completed his candidate dissertation in 1983 and taught for several years in the History Faculty at St. Petersburg State University. There he was the center of a devoted cadre of serious history students who were trying to break out of the mold of pre. scribed dogma. His freethinking interpretations made him a leader for St. Petersburg students and scholars engaged in reinterpreting their past. In America, he held teaching positions at Washington and Lee University and the University of California at Riverside, and he lectured in many other places in the United States, Ireland, France, Poland, Czechoslovakia, and Canada.

Viktor Bortnevskii wrote or edited eight books, and his nearly two hundred ar. ticles appeared in both scholarly and popular publications. He was the founder and editor in chief of the first post-Soviet Russian documentary journal, Russkoe proshloe, which has published continuously since 1991 . He also served as an editor or contributing writer for Novyi chasovoi, Smena, Chas pik, Vechernii Peterburg, Nevskoe vremia, Uch itel'skaia gazeta, and Sobesedik. In the early 1990 s he worked as a scriptwriter, director, and translator for ten historical documentary films and television programs in St. Petersburg. For him, scholarly study was not merely a matter of dusty archives and dry books; it was alive, and he was a master at communicating that life to all kinds of people.

In his all too short career, his work was recognized by the award of fellowships from the International Research and Exchanges Board, the Kennan Institute for Advanced Russian Study, the Hoover Institution, Yale University, the Mellon Foundation, and the Toronto Centre for Russian and East European Studies. An erudite scholar, he worked in the Russian, English, Ukrainian, Belorussian, Polish, German, and French languages.

Viktor was also an outgoing and warm human being. He was collegial, open, and remarkably generous about sharing his research with others. In St. Petersburg, he was a beacon for visiting scholars and was always willing to take the time to discuss their research with them and to help them with their work in the city he loved. He was always giving and helping, never expecting anything in return. We are all poorer for his passing.

\author{
RichaRD Bidlack \\ Washington and Lee University \\ JEFFREY Burds \\ Rochester University \\ William Chast \\ University of Pittsburgh \\ J. ARch GritTy \\ University of California, Riverside \\ Donald RaL.i.g. \\ University of North Carolina \\ May 1996
}

